\title{
ORAL HEALTH CONDITIONS AMONG THE ELDERLY IN SOUTHEASTERN SÃO PAULO STATE
}

\author{
Rafael da Silveira MOREIRA, Lucélia Silva NICO², Nilce Emy TOMITA ${ }^{3}$
}

1- DDS, MSc, Graduate student, Department of Epidemiology, School of Public Health, University of São Paulo, São Paulo, SP, Brazil. 2- DDS, MSc, Graduate student, Department of Public Health Practice, School of Public Health, University of São Paulo, São Paulo, SP, Brazil. 3- DDS, MSc, PhD, Associate Professor, Department of Pediatric Dentistry, Orthodontics and Community Health, Bauru School of Dentistry, University of São Paulo, Bauru, SP, Brazil.

Corresponding address: Rafael da Silveira Moreira - (NESC-CPqAM-Fiocruz) Av. Prof. Morais Rego - Campus da UFPE - Cidade Universitária - s/n Recife - PE - 50670-420 - Phone: + 55 81-2101-2664 - e-mail: moreirars@cpqam.fiocruz.br

Received: April 19, 2008 - Accepted: November 30, 2008

\begin{abstract}
$O$ bjective: This study aimed to asses oral health conditions in a population aged 60 years and over living in Botucatu, Southeastern Brazil. A cross-sectional population-based study was carried out using a random sample $(\mathrm{N}=372)$ of the urban population aged 60 years and over from the city of Botucatu, in 2005. World Health Organization criteria and codes for oral health epidemiological surveys were used. Re-examination was carried out in $10 \%$ of individuals aiming to evaluate intra-examiner agreement. Statistical analysis was performed by one-way ANOVA or Kruskal-Wallis ANOVA, as applicable. Also, the t-test was used in the absence of homoscedasticity. Fisher's exact test was used for situations where the categories with less than five units were observed. Adjusted residuals and multiple-comparison analysis were conducted to identify associations between variable categories and subgroups. The intra-examiner agreement was $98 \%$ and Kappa statistics result was 0.95 . Loss component represented 90.68\% of DMF-T index, which was 29.85 . The prevalence of edentulism was $63.17 \%$. Upper and lower dentures were found in $80 \%$ and $58 \%$ respectively, with complete denture as the most commonly used. In those studied, $15 \%$ required upper and $38 \%$ lower dentures. There was more need for complete denture in both jaws. Approximately $20 \%$ had soft tissue alterations. For periodontal conditions, most sextants were excluded $(81.81 \%)$. Periodontal pockets $(4-5 \mathrm{~mm})$ were seen in $11.29 \%$ of the examined individuals. The oral health status of the elderly population in Botucatu is poor, as well as in other Brazilian cities. The results of this study may help planning collective health actions, giving an accurate description of the oral problems among the elderly.
\end{abstract}

Key words: Oral health. Elderly. Dental health surveys. Aging health.

\section{INTRODUCTION}

The world demographic moment is represented by the evident process of population aging. In spite of being a global phenomenon, each country shows different moments. Heterogeneity is the main mark of this demographic scenario and it can be observed among different nations (international approach) or even among cities, and also between neighborhoods of the same city (local approach).

The demographic and epidemiological transitions in which many countries have been going through indicate an urgent need to search for both producing and product aspects of these changes: population aging and living and health conditions of the elderly. Among various health aspects, oral health stands in an urgent position ${ }^{15}$.

Despite the increased research on the health conditions of the elderly, including oral health, the majority of these studies refer to institutionalized populations. There are few epidemiological population-based studies that refer to oral health conditions of the elderly. In Brazil, studies that describe the epidemiological status of oral health are rare in a national level. The epidemiological evidence from the Health Ministry between 1986 and 1996 gave priority to students and did not focus on individuals aged 60 years or more.

A research on the oral health conditions of the Brazilian population was conducted in the year 2000 (Project SB BRASIL 2003). The national average of decayed, missing and filled teeth (DMF-T index) for individuals aged 65 to 74 years, was 27.93. The "missing" component had a major participation in the percent composition of the DMF-T index $(92.16 \%)$. In relation to the need for denture placement, $56 \%$ and $32.4 \%$ needed lower and upper dentures, respectively, complete denture being the most needed one, indicating a high prevalence of edentulism ${ }^{4}$.

According to the World Health Organization ${ }^{20}$ (WHO), epidemiological oral health studies help determining the extension of oral health treatments in relation to its demand, 
nature and extension of the preventive, curative and restoring services and the resources needed to establish, maintain, expand or reduce dental care planning and policies. They include an estimate of the number and type of human resources needed, permitting the redirection of health practices and the evaluation impact of the proposed measures.

Therefore, this paper reports the investigation of the oral health conditions of the elderly population aged 60 years or more of the city of Botucatu, SP, by means of an epidemiological survey about the oral health of these individuals.

\section{MATERIAL AND METHODS}

\section{Field of Study}

The present study was approved by the Research Ethics Committee of the Medical School of Botucatu, São Paulo State University (Protocol number 220/2004).

The study was conducted in the urban area of the city of Botucatu, Southeastern Brazil. The results of the 2000 Census of the Population, held by the Brazilian Institute for Geography and Statistics (IBGE) ${ }^{10}$ registered a total population of 108,306 inhabitants, and among these, 103,993 people living in the urban area. The population aged 60 years or over was of approximately 12 thousand people, representing $11 \%$ of the total population.

\section{Inclusion criteria}

The study included individuals aged 60 years or over, residents of the urban area of Botucatu who agreed to participate in the survey. The people enrolled in the study were informed and clarified about the objectives and procedures that were to be developed, the confidentiality of the information and the right to decide whether or not to participate in the survey.

\section{Study Design}

An epidemiological survey of oral health conditions of the people over 60 was held (cross-sectional study) by using the codes and criteria suggested by the WHO for epidemiological surveys in oral health ${ }^{20}$.

\section{Sampling}

The population of the study was composed by a randomized sample of individuals aged 60 years or over, who lived in the urban area of Botucatu.

The sample size was determined based on an unknown prevalence $(50 \%)$, establishing an error $\alpha$ of 0.05 and an error $\beta$ of 0.10 . The estimated population with a minimum of individuals aged 60 and over to be examined was of 372 . The selection of individuals for the study was based on the sample process taken from a study on labor accidents in Botucatu $^{9}$, in which a proportional and randomized sample was taken through conglomerate systematic households with the help of the Census of the population of Botucatu. The amount of households of the urban area of the city was estimated in 28,468 in 1997 , being one in four systematically allocated. Later, households having people aged 60 years or more were enumerated and a total of 4,089 people in this condition were located. Among these, the ones that participated in the study were selected through a randomized sequence number until the desired number of individuals was reached $(n=372)$.

\section{Characterization of the Instruments and Variable Description}

DMF-T index was used by examining the conditions of the crown; information on the use and need for dental denture; evaluation on the alteration of the soft tissue, and evaluation of periodontal conditions using two indicators: Community Periodontal Index (CPI) and Clinical Attachment Loss (CAL).

\section{Data collection procedures}

Only one dentist took part in this study in order to simplify the operational process of data collection. However, $10 \%$ of the individuals were re-examined. This procedure was used to estimate the intra-examiner agreement.

The exams were held in the participant's home. The place and organization of the exam areas were defined according to availability, and natural lighting, ventilation and proximity to a water source were required. The exams were conducted with the use of flat dental mirrors, wooden spatula and CPI "ball point" periodontal probes.

Sample loss was characterized when after three visits to the house, including on weekends and phone contacts, the individual could not be located.

\section{Analysis of the Results}

The difference between groups, according to sex and age group, was calculated by analysis of variance (one-way ANOVA or Kruskal-Wallis ANOVA), as applicable. Also, the t-test was used correctly in the absence of homoscedasticity. Fisher's Exact Test was used for situations where the categories with less than five units were observed. Adjusted residuals (to recognize values that had presented positive excesses of counting to a level of $2.5 \%$ one-tail significance) and multiple-comparison analysis were conducted to identify associations between variable categories and subgroups. For data processing, statistic package SPSS ${ }^{\circledR}$ and Statistica ${ }^{\circledR}$ were used.

\section{RESULTS}

The percentage of intra-examiner agreement and the Kappa statistic were, respectively, $98 \%$ and 0.95 , representing excellent agreement and accuracy.

The age range varied from 62 to 93 years, and mean and median values were $72.33( \pm 6.85)$ and 72 years, respectively. The groups with ages between 60 and 64; 65 and 74 ; and 75 years or more represented respectively, $15 \%$, $47 \%$ and $37 \%$. Females represented $62 \%$ of the sample. The average of the DMF-T index was $29.85( \pm 4.12)$, with 
TABLE 1- Distribution of DMF-T means and percentages and its components according to age and sex group, Botucatu, 2005

\begin{tabular}{|c|c|c|c|c|c|c|}
\hline Sex & $\mathbf{N}$ & $\begin{array}{l}\text { Decayed }^{*} \\
\text { Mean (\%) }\end{array}$ & $\begin{array}{l}\text { Filled/Decayed } \\
\text { Mean (\%) }\end{array}$ & $\begin{array}{l}\text { Filled } \\
\text { Mean (\%) }\end{array}$ & $\begin{array}{l}\text { Missing* } \\
\text { Mean (\%) }\end{array}$ & $\begin{array}{l}\text { DMF-T* }^{\star} \\
\text { Mean (\%) }\end{array}$ \\
\hline $\begin{array}{l}\text { Male } \\
\text { Female } \\
\text { Total }\end{array}$ & $\begin{array}{l}141 \\
231 \\
372\end{array}$ & $\begin{array}{l}0.52(1.8) \\
0.20(0.7) \\
\mathbf{0 . 3 2}(\mathbf{1 . 0 )}\end{array}$ & $\begin{array}{l}0.05(0.2) \\
0.06(0.2) \\
\mathbf{0 . 0 6}(\mathbf{0 . 2})\end{array}$ & $\begin{array}{l}2.88(9.8) \\
2.12(7.0) \\
2.41(8.1)\end{array}$ & $\begin{array}{l}25.82(88.2) \\
27.84(92.1) \\
27.07(90.7)\end{array}$ & $\begin{array}{l}29.26(100.0) \\
30.21(100.0) \\
29.85(100.0)\end{array}$ \\
\hline $\begin{array}{l}\text { Age } \\
\text { group } \\
\text { (years) }\end{array}$ & $\mathbf{N}$ & $\begin{array}{l}\text { Decayed } \\
\text { Mean (\%) }\end{array}$ & $\begin{array}{l}\text { Filled/Decayed } \\
\text { Mean (\%) }\end{array}$ & $\begin{array}{l}\text { Filled }^{\star *} \\
\text { Mean (\%) }\end{array}$ & $\begin{array}{l}\text { Missing } \\
\text { Mean (\%) }\end{array}$ & $\begin{array}{l}\text { DMF-T* } \\
\text { Mean (\%) }\end{array}$ \\
\hline 60 to 64 & 56 & $0.30(1.1)$ & $0.09(0.3)$ & $4.52(15.8)$ & 23.63 (82.8) & $28.54(100.0)$ \\
\hline 65 to 74 & 176 & $0.40(1.3)$ & $0.05(0.2)$ & $2.78(9.5)$ & $26.13(89.0)$ & $29.36(100.0)$ \\
\hline 75 or more & 140 & $0.23(0.7)$ & $0.05(0.2)$ & $1.1(3.5)^{\# \#}$ & $29.64(95.6)^{\#}$ & $31.00(100.0)^{\#}$ \\
\hline Total & 372 & $0.32(1.0)$ & $0.06(0.2)$ & $2.41(8.1)$ & $27.07(90,7)$ & $29.85(100.0)$ \\
\hline
\end{tabular}

* Statistically significant difference between sex $(p<0.05)$ - T-Test corrected in the absence of homocedasticity.

** Statistically significant difference between the age groups $(p<0.05)$ - one-Way ANOVA and Kruskal-Wallis ANOVA "Different from age group of 65 to 74 years and from age group of 60 to 64 years $(p<0.05)$

\#Different from age group of 60 to 64 years $(p<0.05)$ - Kruskal-Wallis multiple comparisons.

TABLE 2- Elderly distribution according to the better periodontal conditions evaluated by Community Periodontal Index (CPI), in relation to sex and age group, Botucatu, 2005

\begin{tabular}{|c|c|c|c|c|c|c|}
\hline \multirow[b]{4}{*}{$\mathrm{CPI}^{*}$} & \multirow{4}{*}{$\begin{array}{l}60 \text { to } 64 \\
\text { years } \\
\% \text { row } \\
\text { \%column }\end{array}$} & \multicolumn{2}{|l|}{ Age group } & \multirow[t]{3}{*}{ TOTAL } & \multicolumn{2}{|c|}{ Sex } \\
\hline & & \multirow{3}{*}{$\begin{array}{l}65 \text { to } 74 \\
\text { years } \\
\text { \% row } \\
\text { \%column }\end{array}$} & \multirow{3}{*}{$\begin{array}{l}75 \text { years } \\
\text { or more } \\
\% \text { row } \\
\text { \%column }\end{array}$} & & \multirow{3}{*}{$\begin{array}{l}\text { Male } \\
\text { \% row } \\
\text { \%column }\end{array}$} & \multirow{3}{*}{$\begin{array}{l}\text { Female } \\
\text { \% row } \\
\text { \%column }\end{array}$} \\
\hline & & & & & & \\
\hline & & & & $\begin{array}{l}\text { \% row } \\
\text { \%column }\end{array}$ & & \\
\hline \multirow[t]{2}{*}{ Healthy } & 33.33 & 33.33 & 33.33 & 100.00 & 42.86 & 57.14 \\
\hline & $12.50^{\#}$ & 3.98 & 5.00 & 5.65 & 6.38 & 5.19 \\
\hline \multirow[t]{2}{*}{ Bleeding } & 25.00 & 58.33 & 16.67 & 100.00 & 33.33 & 66.67 \\
\hline & 5.36 & 3.98 & 1.43 & 3.23 & 2.84 & 3.46 \\
\hline \multirow[t]{2}{*}{ Calculus } & 15.15 & 57.58 & 27.27 & 100.00 & 39.39 & 60.61 \\
\hline & 8.93 & 10.80 & 6.43 & 8.87 & 9.22 & 8.66 \\
\hline \multirow[t]{3}{*}{ 4-5 mm Pocket } & 14.90 & 54.76 & 30.95 & 100.00 & 50.50 & 50.50 \\
\hline & 10.71 & 13.07 & 9.29 & 11.29 & 14.89 & 9.09 \\
\hline & 25.00 & 62.50 & 12.50 & 100.00 & 50.50 & 50.50 \\
\hline \multirow[t]{2}{*}{$\geq 6 \mathrm{~mm}$ Pocket } & 10.71 & 8.52 & 2.14 & 6.45 & 8.51 & 5.19 \\
\hline & 12.08 & 43.75 & 44.17 & 100.00 & 34.17 & 65.83 \\
\hline \multirow[t]{2}{*}{ Excluded } & 51.79 & 59.66 & $75.71^{\#}$ & 64.52 & 58.16 & 68.40 \\
\hline & 15.05 & 47.31 & 37.63 & 100.00 & 37.90 & 62.10 \\
\hline TOTAL & 100.00 & 100.00 & 100.00 & 100.00 & 100.00 & 100.00 \\
\hline
\end{tabular}

* Statistically significant difference between the age groups - Fisher's exact test $(p<0.05)$

\# Significant associations between categories $(p<0.05)$. 
confidence interval of $95 \%$ among the values 29.43 and 30.27 , median of 32, minimum value of 7 and maximum of 32. Table 1 shows DMF-T index and its components according to sex and age group. Women presented a higher DMF-T index when compared to men $(\mathrm{p}<0.05)$, even though men presented a higher incidence of decayed $(\mathrm{p}<0.05)$ and filled teeth $(\mathrm{p}>0.05)$; the difference can be explained by a higher "missing component" among women (92.1\% among women and $88.2 \%$ among men). The DMF-T index also presented a variation in relation to age group, being of 28.54 in the younger group (60 to 64 years), 29.36 in the intermediate ( 65 to 74 years) and 31 in the oldest ( 75 years of more), with statistical significance $(\mathrm{p}<0.05)$.

In relation to the periodontal conditions, the majority of the sextants were excluded from the study for not presenting the minimum of two teeth without indication of extraction. The results revealed a significant loss of teeth. Among the examined sextants, most of them were healthy. However, when analyzing people with the best periodontal conditions, we found a larger number of individuals with 4 to $5 \mathrm{~mm}$ pockets in $11.29 \%$ of the individuals (Table 2 ).

Analysing the differences according to sex (Table 2), we observed that the excluded condition and gum bleeding was higher among women, although the presence of calculus and pockets was more expressive among male individuals. This difference, though, showed no statistical significance $(\mathrm{p}>0.05)$. The results indicate that men presented more preserved teeth, but their periodontal conditions were worse than those found in women.

The proportion of excluded individuals was higher in the older group. On the other hand, a smaller proportion of individuals with healthy sextants was found among the group from 65 to 74 years, and also a higher proportion of elderly with calculus and 4 and $5 \mathrm{~mm}$ pockets. Through the analysis of adjusted residuals, an association was observed between the healthy periodontal condition and the younger group, as well as the excluded condition being associated to the older group.

In relation to clinical attachment loss (CAL) (Table 3), a higher percentage of sextants without periodontal insertion loss ( $0 \mathrm{~mm}$ to $3 \mathrm{~mm}$ ) was observed. Secondly, we observed that approximately $10 \%$ of the people presented insertion loss between $6 \mathrm{~mm}$ and $8 \mathrm{~mm}$. In relation to sex, men presented higher incidence of CAL in the categories 4-5 $\mathrm{mm}, 6-8 \mathrm{~mm}$ and $=12 \mathrm{~mm}$. Healthy insertion $(0-3 \mathrm{~mm})$ predominated among women. In the analysis of adjusted residuals, the presence of loss of $6 \mathrm{~mm}$ to $8 \mathrm{~mm}$ was found associated to the male $(\mathrm{p}<0.05)$. The absence of CAL was associated to the younger group. Loss of $9 \mathrm{~mm}$ to $11 \mathrm{~mm}$ was associated to the intermediate group (65 to 74 years) and the excluded sextant was the most common condition among the oldest group.

From the total of 372 elders, 235 did not present any teeth, representing $63.17 \%$ of the surveyed elders. Women

TABLE 3- Elderly distribution according to the better periodontal conditions evaluated by Clinical Attachment Loss (CAL), in relation to sex and age group, Botucatu, 2005

\begin{tabular}{|c|c|c|c|c|c|c|}
\hline \multirow[b]{4}{*}{$C A L^{*, * *}$} & \multirow{4}{*}{$\begin{array}{l}60 \text { to } 64 \\
\text { years } \\
\% \text { row } \\
\text { \%column }\end{array}$} & \multicolumn{2}{|l|}{ Age group } & \multirow[t]{2}{*}{ TOTAL } & \multicolumn{2}{|c|}{ Sex } \\
\hline & & & & & Male & Female \\
\hline & & $\begin{array}{c}65 \text { to } 74 \\
\text { years }\end{array}$ & $\begin{array}{l}75 \text { years } \\
\text { or more }\end{array}$ & \multirow{2}{*}{$\begin{array}{l}\text { \% row } \\
\text { \%column }\end{array}$} & \multirow{2}{*}{$\begin{array}{l}\text { \% row } \\
\text { \%column }\end{array}$} & \multirow{2}{*}{$\begin{array}{l}\text { \% row } \\
\text { \%column }\end{array}$} \\
\hline & & $\begin{array}{l}\text { \% row } \\
\text { \%column }\end{array}$ & $\begin{array}{l}\text { \% row } \\
\text { \%column }\end{array}$ & & & \\
\hline \multirow[t]{2}{*}{$0-3 \mathrm{~mm}$} & 24.56 & 50.88 & 24.56 & 100.00 & 29.82 & 70.18 \\
\hline & $25.00^{\#}$ & 16.48 & 10.00 & 15.32 & 12.06 & 17.32 \\
\hline \multirow[t]{2}{*}{ 4-5 mm } & 14.29 & 57.14 & 28.57 & 100.00 & 42.86 & 57.14 \\
\hline & 7.14 & 9.09 & 5.71 & 7.53 & 8.51 & 6.93 \\
\hline \multirow[t]{2}{*}{$6-8 \mathrm{~mm}$} & 21.62 & 51.35 & 27.03 & 100.00 & 72.97 & 27.03 \\
\hline & 14.29 & 10.80 & 7.14 & 9.95 & $19.15^{\#}$ & 4.33 \\
\hline \multirow[t]{2}{*}{$9-11 \mathrm{~mm}$} & 0.00 & 85.71 & 14.29 & 100.00 & 14.29 & 85.71 \\
\hline & 0.00 & $3.41^{\#}$ & 0.71 & 1.88 & 0.71 & 2.60 \\
\hline \multirow[t]{2}{*}{$12 \mathrm{~mm}$ and + } & 33.33 & 33.33 & 33.33 & 100.00 & 66.67 & 33.33 \\
\hline & 1.79 & 0.57 & 0.71 & 0.81 & 1.42 & 0.43 \\
\hline \multirow[t]{2}{*}{ Excluded } & 12.08 & 43.75 & 44.17 & 100.00 & 34.17 & 65.83 \\
\hline & 51.79 & 59.66 & $75.71^{\#}$ & 64.52 & 58.16 & 68.40 \\
\hline \multirow[t]{2}{*}{ TOTAL } & 15.05 & 47.31 & 37.63 & 100.00 & 37.90 & 62.10 \\
\hline & 100.00 & 100.00 & 100.00 & 100.00 & 100.00 & 100.00 \\
\hline
\end{tabular}

* Statistically significant difference between the age groups - Fisher's exact test $(p<0.05)$.

** Statistically significant difference between sex - Fisher's exact test $(p<0.05)$.

\# Significant associations between categories $(p<0.05)$. 
contributed with a high number of edentulous. From 235 edentulous, 156 were women $(66.38 \%)$ against only 79 men $(33.62 \%)$. The prevalence of edentulous among women was of $67 \%$ and $56 \%$ among men.

Analyzing the use and need for denture in relation to sex and age group, (Tables 4 and 5), we observed that women used more upper and lower dentures and that the use of denture increases when it comes to the older group. Consequently, women presented a lower need to upper and lower dentures. As for the age groups, a lower proportion of individuals that need denture in the older group was registered, since it is the group with a higher prevalence of

TABLE 4- Distribution of the elderly according to the use and need for denture in relation to age group. Botucatu, Brazil, 2005

\begin{tabular}{|c|c|c|c|c|}
\hline Age group & $\begin{array}{l}60 \text { to } 64 \\
\text { years } \\
\end{array}$ & $\begin{array}{c}65 \text { to } 74 \\
\text { years }\end{array}$ & $\begin{array}{r}75 \text { years } \\
\text { or more } \\
\end{array}$ & Total \\
\hline \multicolumn{5}{|l|}{$\begin{array}{l}\text { Use of upper denture* } \\
\mathrm{n}(\% \text { in column) }\end{array}$} \\
\hline Do not use & $16(28.6)$ & $39(22.2)$ & $19(13.6)$ & 74 (19.9) \\
\hline Fixed denture (FD) & $1(1.8)$ & $3(1.7)$ & $1(0.7)$ & $5(1.3)$ \\
\hline More than one denture & $2(3.6)^{\star \star}$ & $1(0.6)$ & $0(0.0)$ & $3(0.8)$ \\
\hline Removable Partial Denture (RPD) & $3(5.4)$ & $9(5.1)$ & $5(3.6)$ & $17(4.6)$ \\
\hline One or + FD/RPD & $1(1.8)^{\star \star}$ & $0(0.0)$ & $0(0.0)$ & $1(0.3)$ \\
\hline Complete denture & $33(58.9)$ & $124(70.5)$ & $115(82.1)^{\star \star}$ & $272(73.1)$ \\
\hline \multicolumn{5}{|l|}{$\begin{array}{l}\text { Use of lower denture } \\
\mathrm{n} \text { ( } \% \text { in column) }\end{array}$} \\
\hline Do not use & $30(53.6)$ & $81(46.0)$ & $45(32.1)$ & $156(41.9)$ \\
\hline Fixed denture (FD) & $0(0.0)$ & $3(1.7)$ & $2(1.4)$ & $5(1.3)$ \\
\hline More than one fixed denture & $0(0.0)$ & $1(0.6)$ & $0(0.0)$ & $1(0.3)$ \\
\hline Removable partial denture (RPD) & $8(14.3)$ & $19(10.8)$ & $20(14.3)$ & $47(12.6)$ \\
\hline One or + FD/RPD & $0(0.0)$ & $2(1.1)$ & $0(0.0)$ & $2(0.5)$ \\
\hline Complete denture & $18(32.1)$ & $70(39.8)$ & 73 (52.1) & $161(43.3)$ \\
\hline
\end{tabular}

Need for upper denture

$\mathrm{n}$ (\% in column)

Do not need

One FD or RPD (1 element)

One FD or RPD(+ than 1 element)

Denture combination

Complete denture

$46(82.1)$
$2(3.6)$
$2(3.6)$
$1(1.8)$
$5(8.9)$

$146(83.0)$

$3(1.7)$

$3(1.7)$

$5(2.8)$

$19(10.8)$

$\begin{aligned} 122 & (87.1) \\ 1 & (0.7) \\ 3 & (2.1) \\ 0 & (0.0) \\ 14 & (10.0)\end{aligned}$

314 (84.4)

$6(1.6)$

8 (2.2)

6 (1.6)

$38(10.2)$

\section{Need for lower denture* \\ n (\% in column)}

Do not need

One FD or RPD (1 element)

One FD or RPD(+ than 1 element)

Denture Combination

Complete denture

$33(58.9)$
$4(7.1)^{\star \star}$
$7(12.5)$
$1(1.8)$
$11(19.6)$

$56(100.0)$

$\begin{array}{cc}103(58.5) & 93(66.4) \\ 1(0.6) & 0(0.0) \\ 27(15.3) & 11(7.9) \\ 11(6.3)^{\star \star} & 2(1.4) \\ 34(19.3) & 34(24.3)\end{array}$

$229(61.6)$

5 (1.3)

45 (12.1)

14 (3.8)

79 (21.2)

\section{Total}

n (\% In column)

$176(100.0)$

$140(100.0)$

372 (100.0)

* Statistically significant difference - Fisher's exact test $(p<0.05)$.

** Significant associations between groups $(p<0.05)$. 
denture use.

Residual analysis revealed that male individuals represent the group with lower upper and lower denture need. Conversely, women are the individuals with higher prevalence of complete denture use (upper and lower). The results according to age group show that the younger group presented a higher use of more than one fixed denture or combination of partial upper fixed and removable dentures. The older group was associated to a greater use of total upper denture. The need for a lower fixed or removable partial single-unit denture was associated to the younger group. The need for combination with lower denture was

TABLE 5- Elderly distribution according to use and need for dental denture in relation to sex. Botucatu, Brazil, 2005

\begin{tabular}{|c|c|c|c|}
\hline Sex & Male & Female & Total \\
\hline \multicolumn{4}{|l|}{$\begin{array}{l}\text { Use of Upper Denture* } \\
\text { n ( } \% \text { in column) }\end{array}$} \\
\hline Do not use & $40(28.4)^{\star \star}$ & $34(14.7)$ & 74 (19.9) \\
\hline Fixed denture ( FD) & $3(2.1)$ & $2(0.9)$ & $5(1.3)$ \\
\hline More than one fixed denture & $0(0.0)$ & $3(1.3)$ & $3(0.8)$ \\
\hline Removable partial denture (RPD) & $4(2.8)$ & $13(5.6)$ & $17(4.6)$ \\
\hline One or + FD/RPD & $0(0.0)$ & $1(0.4)$ & $1(0.3)$ \\
\hline Complete denture & $94(66.7)$ & $178(77.1)^{\star \star}$ & $272(73.1)$ \\
\hline
\end{tabular}

\section{Use of Lower Denture*}

n (\% in column)

$\begin{array}{lccc}\text { Do not use } & 71(50.4)^{\star \star} & 85(36.8) & \mathbf{1 5 6}(\mathbf{4 1 . 9}) \\ \text { Fixed Denture (FD) } & 1(0.7) & 4(1.7) & \mathbf{5}(\mathbf{1 . 3}) \\ \text { More than one fixed denture } & 0(0.0) & 1(0.4) & \mathbf{1 ( 0 . 3 )} \\ \text { Removable Partial Denture (RPD) } & 17(12.1) & 30(13.0) & \mathbf{4 7}(\mathbf{1 2 . 6 )} \\ \text { One or + FD/RPD } & 2(1.4) & 0(0.0) & \mathbf{2 ( 0 . 5 )} \\ \text { Complete denture } & 50(35.5) & 111(48.1)^{\star \star} & \mathbf{1 6 1}(\mathbf{4 3 . 3 )}\end{array}$

\section{Need for Upper Denture \\ $\mathrm{n}$ (\% in column)}

\begin{tabular}{|c|c|c|c|}
\hline Do not use & $110(78.0)$ & $204(88.3)$ & 314 (84.4) \\
\hline One FD or RPD(1 element) & $4(2.8)$ & $2(0.9)$ & $6(1.6)$ \\
\hline One FD or RPD (+ than 1 element) & $5(3.5)$ & $3(1.3)$ & $8(2.2)$ \\
\hline Denture combination & $3(2.1)$ & $3(1.3)$ & $6(1.6)$ \\
\hline Complete denture & 19 (13.5) & $19(8.2)$ & $38(10.2)$ \\
\hline
\end{tabular}

\section{Need for lower denture}

n (\% in column)

$\begin{array}{lc}\text { Do not use } & 79(56.0) \\ \text { One FD or RPD (1 element) } & 3(2.1) \\ \text { One FD or RPD (+ than 1 element) } & 21(14.9) \\ \text { Denture combination } & 6(4.3) \\ \text { Complete denture } & 32(22.7)\end{array}$

$$
\begin{gathered}
150(64.9) \\
2(0.9) \\
24(10.4) \\
8(3.5) \\
47(20.3)
\end{gathered}
$$

\section{Total}

n (\% in column)

$141(100.0)$

* Statistically significant difference - Fisher's exact test $(p<0.05)$

** Significant associations between groups $(p<0.05)$. 
higher in the intermediate group (60 to 75 years).

Approximately $20 \%$ of the participants presented some kind of oral lesion. There was a higher prevalence among women $(22 \%)$ than men $(17 \%)$.

\section{DISCUSSION}

The method proposed in the present study allowed the knowledge of the profile of oral health among the elderly residing in the urban area of Botucatu, SP, Brazil. The use of a randomized sample of the elder population represented an important contribution for the comprehension of the oral health-disease process among the elderly, since the majority of the national studies that focused on this population group was restricted to convenience samples, such as health center patients, institutionalized elders and community center users $^{7,15}$.

The DMF-T index found in the present study, in the age group from 65 to 74 years $(29.36 \pm 4.57)$, was considered high in relation to other international studies that followed the same methodology. Considering the WHO index group, in a transversal survey held in the province of Guangdong (China), Lin, et al. ${ }^{12}$ (2001) registered a DMF-T of 14.7 among the elderly living in the urban area. In Hong Kong ${ }^{13}$, the DMF-T index was 18.9, and in Lithuan ${ }^{18}$ this index was 24. Slade, et al. ${ }^{19}$ (1993), studying no institutionalized elders aged 60 years or more, in the city of Adelaide (Australia), found a DMF-T index of 24.3.

In Brazil, regional studies were held in the southeastern region using convenience samples mainly. The DMF-T index found in Botucatu is similar to the average values of the different local epidemiological studies ${ }^{15}$ that vary from 25 to 31 .

In Botucatu, the prevalence of edentulism (63.17\%) was high when compared to international studies. In Hong Kong ${ }^{8}$ only $12 \%$ were edentulous. In the south of China, prevalence of edentulism is even lower: only $4.4 \%$ of the elders living in the urban area presented this condition ${ }^{12}$; in Lithuania, $11 \%$ were edentulous ${ }^{18}$; in India ${ }^{17}$, the prevalence was $15 \%$; in France ${ }^{3}$ the percentage was $16.3 \%$; in Ontario ${ }^{14}$ (Canada), was of $24.4 \%$; in Sweden ${ }^{16}$, was $31.5 \%$, and in Adelaide ${ }^{19}$ (Australia), the prevalence of edentulism was $47.7 \%$.

A study that could be considered similar in relation to the use of randomized samples was conducted by Colussi, et al. ${ }^{6}$ (2004), with a population aged 60 years or more in Biguaçu (Santa Catarina). In this study, the authors found a prevalence of $48.4 \%$ of edentulous, residents in urban and rural areas.

Even being edentulism a problem of high prevalence among the elderly, few studies describe the use and need for denture, following the guidelines and criteria recommended by WHO. This made the comparison between findings more difficult.

In India, $17.6 \%$ of the elders did not use denture because they were dentate. Only $8.3 \%$ used complete dentures in both jaws, and $7.8 \%$ used removable dentures. Among the 222 partial or total edentulous elders, 103 used complete denture in one or both jaws. In contrary to the present study, a greater use of denture was found among $\operatorname{men}^{17}$.

In Guangdong (China), 51.4\% of the elders between 65 and 74 years of age, residents in the urban area, used some kind of denture. However, only $10.2 \%$ used complete dentures ${ }^{11}$. In Hong Kong ${ }^{8}, 53 \%$ and $62 \%$ did not use denture in the upper and lower jaw, respectively. This result does not reveal a high need for denture, but a low prevalence of edentulism (12\%). Only $21 \%$ and $17 \%$ used total upper and lower denture, respectively. In Adelaide, $83.9 \%$ of the elders used some type of denture, and $45.3 \%$ used total upper and lower denture ${ }^{19}$.

In $\mathrm{Brazil}^{4}$, according to the latest national epidemiologic survey (SB Brasil 2003), the use and need for denture showed a higher proportion of elders that use upper denture $(66.5 \%)$, but there was a lower proportion of elders that use lower denture $(30.9 \%)$. In both jaws, the most common type of denture was the total one, and its use was higher in the upper jaw (57.9\%) in relation to the lower jaw (24.8\%).

Different from the analyzed countries (India and China), Brazil is characterized by an elder population with many users of complete denture and at the same time, with a great need for this type of denture. We found a polarized scenario with users of complete denture and on the other hand, the ones that still need this kind of rehabilitation.

In relation to the periodontal conditions found in the present study, we observed that, even though the majority of the sextants were healthy, there was a larger number of individuals with periodontal pockets measuring 4 to $5 \mathrm{~mm}$ (Table 2). This apparent paradox symbolizes that people with a healthier periodontal condition are also the ones with the higher number of healthy sextants, and, therefore, were not excluded. That is why, even though there are more people with periodontal pocket condition, this group also presented a lower number of examined sextants. Therefore, we have in one hand, a scenario with few people with healthy periodontal conditions and with many healthy sextants, and on the other hand, many people with periodontal pocket conditions, with few sextants able to be examined and in worse conditions.

Burgeois and Doury ${ }^{3}$ (1999), studying periodontal conditions of 603 individuals of 65 to 74 years of age in France, found periodontal alteration in $83.5 \%$ of non edentulous elders. Among these, 39.1\% and 28.6\% presented calculus and pockets of $4 \mathrm{~mm}$ to $5 \mathrm{~mm}$, respectively. Therefore like the results of the present study, when the periodontal conditions of the French elders were analyzed for each sextant, there was a higher average of healthy or bleeding sextants.

Most national studies observed a presence of calculus as the main periodontal alteration found among the elderly ${ }^{15}$. In the most recent national survey (SB Brasil 2003) ${ }^{4}$, in elders of 65 to 74 years old, $80.8 \%$ of the sextants were excluded and $8.3 \%$ presented calculus.

Due to the DMF-T index not be the best indicator of oral health among the elderly and observing the high prevalence of edentulism, measuring the need for denture represents the main treatment priority in elders. Therefore, 
the focus should be on the determinant factors of this need and on the organization of public dental care services that can provide the necessary social response to these people, historically neglected by our oral health care models.

Changes, in general, occur in the whole body during the aging process. The oral health as an inseparable part of that body in constant change, at the same time that is the target of such changes, is also generating the changes throughout life. Knowledge of these changes is necessary in order to avoid confusion between pathological processes and the physiological processes. However, the boundary between the senescence (physiological aging) and senility (pathological aging) does not present a clear demarcation. In the elderly population we can observe a permeability of different conditions, some favorable, other debilitating. It is thus necessary to know the determinants and conditions of health among the elderly.

According to Andreu and Hernández ${ }^{2}$ (2003), the cellular senescence has been implicated in aging. Due to the fact that the senescent cells are incapable of self-renewal, it is proposed that these cells could contribute to phenotypes related to aging, such as immune failure, poor wound healing and skin atrophy, and decreased gastrointestinal function. It is assumed that these phenotypes are due to loss of proliferative capacity of cells and therefore the capacity of regenerative tissue. In that sense, it should be noted that many changes in the oral health of the elderly, such as the decrease in salivation, loss of tooth structure and dental support occur due to the process of biological aging.

Abnet, et al. ${ }^{1}$ (2005) performed a cohort study in Chinese adults and found that increased tooth loss was associated with increased risk of gastrointestinal cancer deaths by heart disease and strokes. These findings demonstrate the important relationship between oral health and other fields of health. Another study conducted by Cabrera, et al. ${ }^{5}$ (2007) found association between the use of psychoactive drugs and low saliva flow rates, signaling the importance of a dialogue between the various fields of elderly health.

This study presents some limitations. It should be noted that the DMF-T index should not be the best indicator of the severity of caries in the elderly, despite its use in scientific literature. The high value found in that index is mainly a result of the "missing" component. The fact that people consider edentulism as having lost all their teeth due to caries may not be a reality for all those people. Moreover, the cumulative nature of caries reflects, in most cases, a more intense severity of caries in the past. Indeed, the root caries presents itself as the most worrying condition in terms of collection of epidemiological data regarding the prevalence of caries in the elderly. More attention is also needed to other root changes with no bacterial origin, such as abrasions, erosions and attrition.

\section{CONCLUSIONS}

In the same way as observed in other Brazilian cities, the oral conditions of the elderly of Botucatu, mainly expressed by the DMF-T index and edentulism prevalence, are far from the goals of international organizations. However, the establishment of objectives is based on data collected from disease status and not information about health conditions. The prioritizing of goals, using a larger number of healthy people instead of a minimum number of sick people, would bring strategic changes for health promotion. The benefits of preventive actions in younger age groups will be fundamental in the future and this will probably result in a smaller number of edentulous. Thus, the present moment asks for initiatives directed to today's elders that can improve their life quality and include them as part of the agenda for oral health, meeting their current needs for restorative and rehabilitation treatment.

\section{ACKNOWLEDGEMENTS}

To DDS, MSc, PhD, Associate Professor Júlio César Rodrigues Pereira for the suggestions in statistical analysis. To the people of Botucatu, SP, especially the elderly, for their collaboration during this population-based study. The authors thank FAPESP for financial support (process n. 04/ 03629-8).

\section{REFERENCES}

1- Abnet CC, Qiao YL, Dawsey SM, Dong ZW, Taylor PR, Mark SD. Tooth loss is associated with increased risk of total death and death from upper gastrointestinal cancer, heart disease, and stroke in a Chinese population-based cohort. Int J Epidemiol. 2005;34:467-74.

2- Andreu GP, Hérnandez RD. Senescencia celular y envejecimiento. Rev Cubana Invest Biomed. 2003;22(3):204-12.

3- Bourgeois DM, Doury J. Periodontal conditions in 65-74 year old adults in France, 1995. Int Dent J. 1999;49:182-6.

4- Brasil. Ministério da Saúde. Projeto SB Brasil 2003: condições de saúde bucal da população brasileira 2002-2003: resultados principais. Brasília: Ministério da Saúde; 2004

5- Cabrera MAS, Mesas AE, Rossato LA, Andrade SM. Fluxo salivar e uso de drogas psicoativas em idosos. Rev Assoc Med Brás. 2007;53(2):178-81.

6- Colussi CF, Freitas SFT, Calvo MCM. Perfil epidemiológico da cárie e do uso e necessidade de prótese na população idosa de Biguaçu, Santa Catarina. Rev Bras Epidemiol. 2004;7:88-97.

7- Colussi CF, Freitas SFT. Aspectos epidemiológicos da saúde bucal do idoso no Brasil. Cad Saude Publica. 2002;18:1313-20.

8- Corbet EF, Lo ECM. Tooth spaces in and prosthetic treatment received by the middle-aged and the elderly in Hong Kong. Community Dent Oral Epidemiol. 1994;22:386-91.

9- Cordeiro R, Sakate MS, Clemente APG, Diniz CS, Donalisio MR. Subnotificação de acidentes do trabalho não fatais em São Paulo, 2002. Rev Saude Publica. 2005;39(2):254-60.

10- Instituto Brasileiro de Geografia e Estatística. Censo demográfico 2000: resultados da amostra; 2000. Disponível em URL: http:// www.ibge.gov.br [2004 abr 14]. 
11- Lin HC, Corbet EF, Lo ECM, Zhang FG. Tooth loss, occluding pairs, and prosthetic status of Chinese adults. J Dent Res. 2001;80:1491-5.

12- Lin HC, Wong MCM, Zhang HG, Lo ECM. Coronal and root caries in southern Chinese adults. J Dent Res. 2001;80:1475-9.

13- Lo ECM, Schwarz E. Tooth and root conditions in the middle-aged and the elderly in Hong Kong. Community Dent Oral Epidemiol. 1994;22:381-5.

14- Locker D, Slade GD, Leake JL. Prevalence of and factors associated with root decay in older adults in Canada. J Dent Res. 1989;68:768-72.

15- Moreira RS, Nico LS, Tomita NE, Ruiz T. A saúde bucal do idoso brasileiro: revisão sistemática sobre o quadro epidemiológico e acesso aos serviços de saúde bucal. Cad Saude Publica. 2005;21(6):1665-75.

16- Palmqvist S. Treatment need and received in an elderly Swedish county population. Gerodontics. 1988;4:272-6.

17- Shah N. Gender issues and oral health in elderly Indians. Int Dent J. 2003;53:475-84

18- Skudutyte R, Aleksejuniene J, Eriksen HM. Dental caries in adult Lithuanians. Acta Odontol Scand. 2000;58:143-7.

19- Slade GD, Spencer AJ, Gorkic E, Andrews G. Oral health status and treatment needs of non-institutionalized persons aged 60+ in Adelaide, South Australia. Aust Dent J. 1993;38:373-80.

20- World Health Organization. Oral health surveys: basic methods. $4^{\text {th }}$ ed. Geneva: ORH/EPID; 1997. 